\title{
PROTECTIVE EFFECT OF CUPCAKE PREPARED BY REPLACING FAT WITH DIFFERENT LEVELS OF BAKED SWEET POTATO ON OBESE RATS
}

\author{
Asmaa A. Hafez(1), Heba E. Youssef(2), E. H. Mansour(1) and A. H. Khalil(1) \\ (1) Food Science and Technology Dept., Faculty of Agriculture, Menoufia University, \\ Shibin El-Kom, Egypt \\ (2) Nutrition and Food Science Dept., Faculty of Home Economics, Menoufia University, \\ Shibin El-Kom, Egypt
}

Received: Mar. 26,2019

Accepted: Apr. 13, 2019

\begin{abstract}
Nowadays, there is an increase interest in natural products as an alternative to replace fat in different food formulations to meet the nutritional demands of consumers. In this sense, the current study utilized baked sweet potato in different levels, due to its high nutritional value and health-promoting properties, to replace fat in the cupcake and produce healthy value-added product. The potential effects of reducedfat cupcake containing baked sweet potato on obese rats were evaluated. The results indicated that body weight gain of obese rats fed reduced fat cupcake diets formulated with baked sweet potato was reduced by $43-63 \%$ compared to positive control rats. Also, the obese rats fed reduced fat cupcake diets at $40-80 \%$ baked sweet potato level for 30 days lead to restoring the normal organs weight of negative control rats. Feeding obese rats with reduced fat cupcake diets prepared with baked sweet potato reduced body weight gain, organs weight, TG, TC, LDL, blood glucose, liver enzymes, and creatinine compared to positive control rats. The non-significant $(P>0.05)$ differences in organ weight, HDL, blood glucose, kidney functions, and liver functions were observed between reduced fat cupcake diets at $5 \%$ and $2.5 \%$ replacement level. While feeding rats with reduced fat cupcake diets at $5 \%$ showed lower $(P \leq 0.05) T G, T C$, and $L D L$ and higher $(P \leq 0.05)$ weight gain than reduced fat cupcake diets at $2.5 \%$. The obtained results proved that baked sweet potato is a suitable natural product which might be incorporated in the production of the cupcake to improve obesity.
\end{abstract}

Key words: Baked sweet potato, cupcake, obese rats, liver and kidney functions, lipoproteins

\section{INTRODUCTION}

Sweet potato (Ipomoea batata L.) is very important crop due to its starchy roots, which can provide energy and nutritive substances that can contribute to enhancing the nutrient status of the consumers (Burri, 2011). Sweet potato is nutritionally good in terms of dietary fiber, certain minerals and vitamin contents which promote different health benefits to the human being ( $\mathrm{Ji}$ et al., 2015). Dietary fiber has positive effects on diabetes and constipation. Vitamins A, $C$, and $E$ present in sweet potato are powerful antioxidants which act against certain cancer and the ravages of aging. In addition to the nutritional values of sweet potato, it has been considered as a functional food due to the high levels of various phytochemicals which might have health beneficial effects (Tsuda et al., 1998). Moreover, sweet potato is among the best sources to prevent vitamin A deficiency (van jaarsveld et al., 2015) and contains anti-inflammatory, anti-diabetic, and anticancer properties (Mohanraj and Sivazankar, 2014). Due to the high nutritional value and healthpromoting properties of sweet potato, many researches have been conducted 
to incorporate sweet potato in baking industry to produce value-added products (Alloush, 2015; Trinidad et al., 2013; Srivastava et al., 2012; Rodriguez et al., 2011). Different forms of sweet potato can be used to supplement wheat flour in bakery products such as steamed, boiled, baked, mashed and flour (Hagenimana et al., 1998).

Recently, there has been increasing interest in the health benefits and an urgent need for safer, lower cost, and more effective bioactive agents to be incorporated in food to produce valueadded and functional food products. Therefore, the current study was designed to produce reduced fat cupcake by partial substitution of fat in the formula of the cupcake with different levels of baked sweet potato. Reduced fat cupcake was used to replace the diets of obese rats at $\mathbf{2 . 5}$ and $\mathbf{5 \%}$ levels.

The objective of this study was to evaluate the effect of feeding obese rats with reduced fat cupcake diets prepared with different levels of baked sweet potato on body weight gain, organs weight, lipid profile, blood glucose, kidney functions, and liver functions.

\section{MATERIALS AND METHODS \\ Materials:}

Sweet potato tuberous roots, (Ipomoea batata L.) Wheat flour (72\% extraction), sugar, butter, fresh yeast, and salt were purchased from the local market at Shibin El-Kom, Menoufia, Egypt. Casein, oil, cellulose, choline chloride, DI-methionine, vitamins mixture, and minerals mixture were obtained from Morgan Co. Cairo, Egypt. Chemical kits for determination total cholesterol, triglyceride, high-density lipoprotein, creatinine, urea, and uric acid, were purchased from El-Gomhoria Company for Chemicals and Drugs ElAmeria, Cairo, Egypt. Adult male albino rats of Sprague Dawley strain $(150 \mathrm{~g} \pm 5)$ were obtained from the Research Institute of Ophthalmology, Animal House Department, Giza, Egypt.

Methods:

Technological methods

Preparation of sweet potato

Sweet potato was carefully washed with tap water. Sweet potato was baked at $160^{\circ} \mathrm{C}$ for $40 \mathrm{~min}$ in an electric draught oven. Raw and baked sweet potatoes were kept at $-10^{\circ} \mathrm{C}$ until use.

\section{Preparation of sweet potato cupcake}

Control cupcake was prepared according to Sudha et al., (2007) with some modifications. The formula included $25.84 \%$ wheat flour, $25.84 \%$ sugar, $31 \%$ egg, $16.8 \%$ margarine, $0.13 \%$ baking powder and $0.39 \%$ salt. Cupcake batter was prepared in a Hobart mixer ( $\mathrm{N}$ 50) using a flour batter method. The flour, margarine, salt and baking powder were creamed together to get a fluffy cream; eggs and sugar were whipped together until semi-firm foam resulted. The sugaregg foam was mixed with the creamed flour and margarine. For each cupcake variation, twelve $50-\mathrm{g}$ portions of batter were weighed and placed in paper baking cups in an aluminum muffin pan. The cupcakes were baked in a $160^{\circ} \mathrm{C}$ oven for $45 \mathrm{~min}$. Cupcakes were cooled to room temperature before use. To prepare the fat replacer treatments, the margarine in the formula was replaced with 20, 40, 60 and $80 \%$ of baked sweet potato. The same order of mixing described for the control was followed.

\section{Biological evaluation \\ Experimental animals}

The work was carried out at Research Institute of Ophthalmology, Animal House Department, Giza, Egypt. Seventytwo male albino rats $(150 \mathrm{~g} \pm 5)$ were fed a standard diet for 7 days as an adaptation period. The standard diet was formulated 
according to AIN-93 guidelines (Reeves et al., 1993) The salt mixture and vitamin mixture were prepared according to Hegested et al. (1941) and Campbell (1961), respectively. The rats were housed individually in wire cages under normal laboratory conditions. Every day the rats were observed for the external appearance, shape, color, and distribution of hair and physical activity. The diets were introduced to rats in special food cups to avoid loss of food and contamination. Also, water was provided to rats by glass tube projecting through wire cages from inverted bottles supported to one side of the cage. Food and water provided were checked daily.

\section{Experimental groups:}

Seventy-two rats were randomly divided into two main groups, the first, negative control group ( $n=6)$, fed standard and the second group $(n=66)$ fed high-calorie diet (fat is $40 \%$ of total calories) for four weeks to achieve obesity according to Kang et al., (2005). The second group $(n=66)$ was divided into 11 subgroups, 6 rats per subgroup. First subgroup is positive control fed standard diet, second subgroup fed standard diet substitution with $2.5 \%$ of control cupcake, third subgroup fed standard diet substitution with $2.5 \%$ of cupcake contains $20 \%$ of baked sweet potato, fourth subgroup fed standard diet substitution with $2.5 \%$ of cupcake contains $40 \%$ of baked sweet potato, fifth subgroup fed standard diet substitution with $2.5 \%$ of cupcake contains $60 \%$ of baked sweet potato, sixth fed standard diet substitution with $2.5 \%$ of cupcake contains $80 \%$ of baked sweet potato, seventh subgroup fed standard diet substitution with $5 \%$ of control cupcake, eighth subgroup fed standard diet substitution with $5 \%$ of cupcake contains $20 \%$ of baked sweet potato, ninth subgroup fed standard diet substitution with $5 \%$ of cupcake contains $40 \%$ of baked sweet potato, tenth subgroup fed standard diet substitution with $5 \%$ of cupcake contains $60 \%$ of baked sweet potato, eleventh subgroup fed standard diet substitution with $5 \%$ of cupcake contains $80 \%$ of baked sweet potato. The dried cupcake was replaced with corn starch in the standard diet at 2.5 and 5\% replacement levels.

\section{Body Weight gain}

All rats were weighed at the beginning (initial weight) and the end of the experiment (final weight) to determine body weight gain according to Chapman et al., (1959) using the following formulas: Body weight gain $(g) \begin{aligned} & =\text { final weight }- \\ & \text { initial weight }\end{aligned}$

\section{Organ weights}

The liver, kidney, and heart were removed from each rat carefully dissection, cleaned from the adhesive matter by a saline solution, dried by filter paper and weighed according to the methods described by Drury and Wallington, (1980).

\section{Blood sampling and preparation}

Blood samples were taken at the beginning and at the end of the experimental period (30 days). The blood samples were collected from orbital plexus venus by means of fine capillary glass tubes according to the method described by Schermer, (1967). The blood samples were placed in dry clean centrifuge tubes and allowed to clot for 1$2 \mathrm{~h}$ at room temperature. Serum was then removed by centrifuging at $1500 \mathrm{~g}$ for 10 min. The clear supernatant serum was kept at $-20^{\circ} \mathrm{C}$ until analysis.

\section{Analytical methods: \\ Serum triglyceride (TG), total cholesterol (TC), and high-density lipoprotein cholesterol (HDL) were determined by using the enzymatic}


colorimetric method as described by Fossati and Prencipe, (1982), Allain et al., (1974), and Assmann (1979), respectively. Low-density lipoprotein (LDL) was carried out according to the method of Lee and Nieman, (1996) as follows:

$\mathrm{LDL}=$ Total cholesterol $-(\mathrm{HDL}+\mathrm{VLDL})$

Serum glucose was estimated according to Trinder, (1969). Uric acid, urea, and creatinine levels were determined according to the method described by Barham and Trinde, (1972), Gutmann and Bergmeyer , (1974) and Houot, (1985), respectively. Alanine aminotransferase (ALT), aspartate aminotransferase (AST) were determined according to the method of Reitman and Frankel, (1957). Alkaline phosphatase (ALP) was determined according to the method of Hayssement, (1977).

\section{Statistical Analysis}

Data were presented as the mean \pm standard deviations. Data were analyzed using a two-way analysis of variance. Comparisons among means were performed using the LSD test. The differences were considered significant at the $5 \%$ level $(p \leq 0.05)$ using Costat version 6.311 (Copyright 1998-2005, CoHort software).

\section{RESULTS AND DISCUSSION}

Effect of baked sweet potato cupcake on body weight gain of rats

Obese rats had higher $(P \leq 0.05)$ initial weights than negative control rats (Table 1). Shin et al., (2013) reported that the body weight of the high-fat diet rats was higher than the normal diet rats. The final weight of rats fed cupcake diets was lower $(P \leq 0.05)$ than positive control rats. On the other side, final weights of rats fed reduced fat cupcake diets were significantly $(P \leq 0.05)$ decreased by increasing the replacement level of baked sweet potato in reduced fat cupcake diets as compared with positive control rats and obese rats fed control cupcake diet. This reduction may be due to the beneficial action of baked sweet potato on body weight gain. Shin et al., (2013) reported that rats fed supplemented purple sweet potato extract diet had lower body weight than those fed the high-fat diet during the six weeks of the experiment period.

Positive control rats had higher $(P \leq 0.05)$ body weight gain than negative control rats and rats fed cupcake diets. Rats fed control cupcake diet had higher $(P \leq 0.05)$ body weight gain than negative control rats and rats fed reduced fat cupcake diets. Body weight gain of rats fed reduced fat cupcake diets was reduced $(P \leq 0.05)$ by increasing the replacement level of baked sweet potato in reduced fat cupcake diets as compared with positive control rats and obese rats fed control cupcake diet. Body weight gain was reduced by $43.14-63.03 \%$ as compared with positive control rats. There is sufficient evidence that the consumption of sweet potato could play an important role in the prevention and development of body weight gain. Although reduced fat cupcake diets at different replacement level of baked sweet potato reduced body weight gain in the obese rats, their values still higher than negative control rats. This may be due to the short of the trial period.

\section{Effect of baked sweet potato cupcake on organ weight \\ Obese rats fed standard diet (positive} control rats) and rats fed control cupcake (full-fat cupcake) diet had higher ( $P \leq 0.05)$ organ weight values than normal rats fed standard diet (negative control rats) and obese rats fed reduced fat cupcake diets (Table 2). Kumar et al., (2012) found that feeding rats high-fat diet (20 g/day) for 28 days resulted in a significant increase in organs weight. A non-significant $(P>0.05)$ differences in organ weight values were 


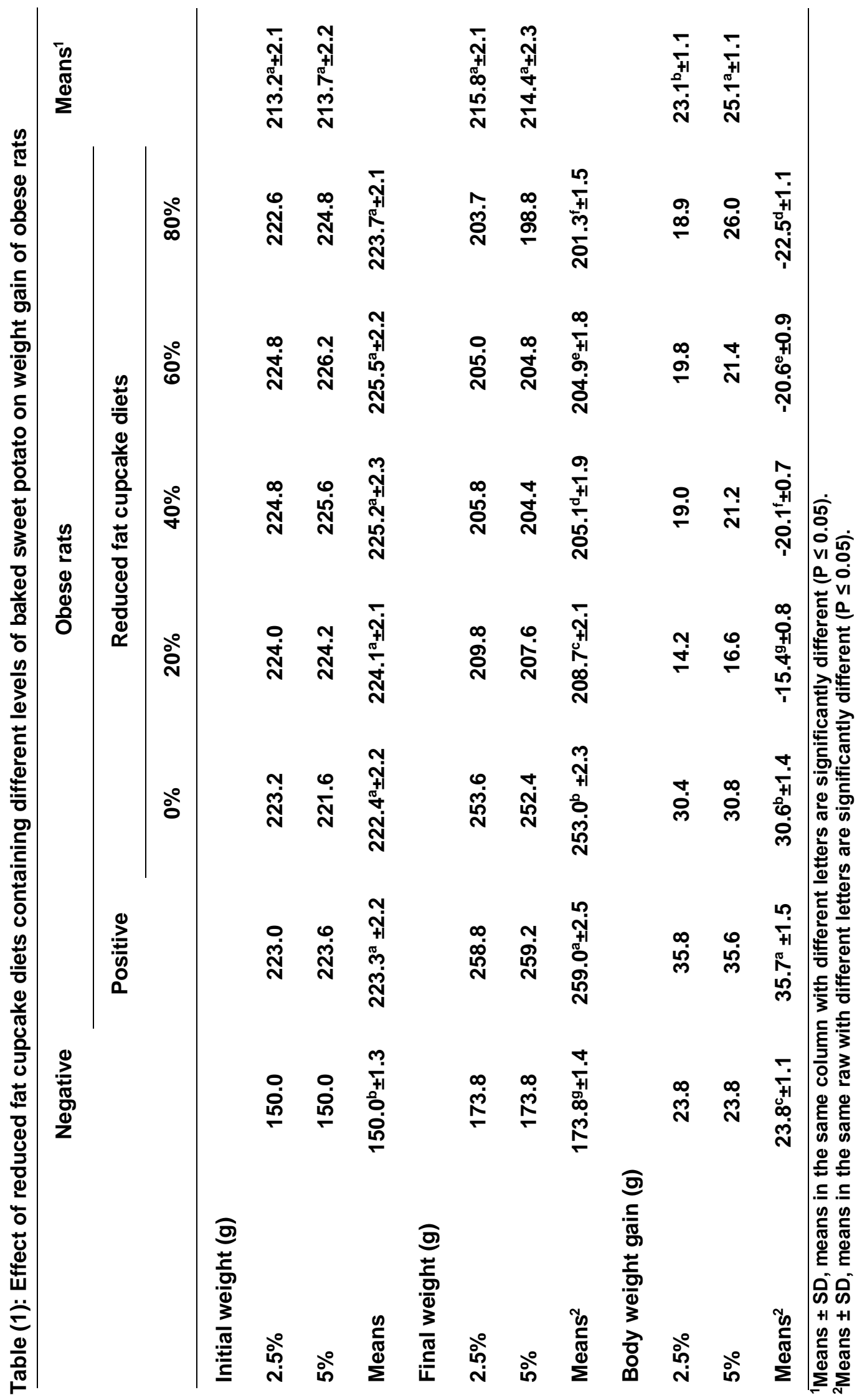




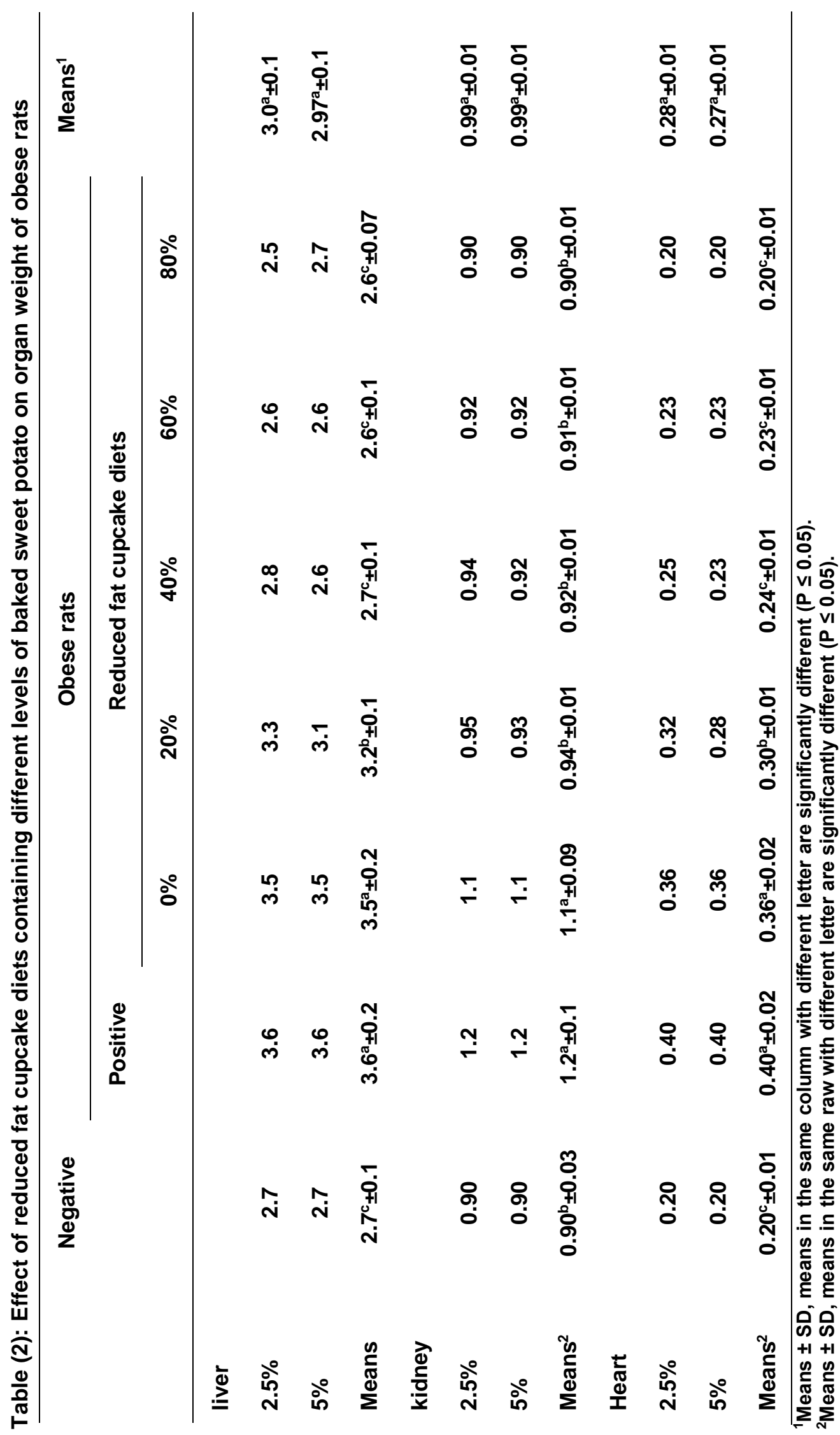


observed between positive control rats and rats fed control cupcake diet. However, organ weight values were significantly $(P \leq 0.05)$ decreased by the replacement level of baked sweet potato in reduced fat cupcake diets as compared with positive control rats and obese rats fed control cupcake diet. Shin et al., (2013) reported that rats fed supplemented purple sweet potato extract diet had lower liver weight than those fed the high-fat diet.

The obese rats fed reduced fat cupcake diets from 40 to $80 \%$ replacement levels for $\mathbf{3 0}$ days lead to restore the normal liver and heart weights of negative control rats. However, obese rats fed reduced fat cupcake diets at any replacement levels for $\mathbf{3 0}$ days lead to restore the normal kidney of negative rats. Data showed the beneficial role of baked sweet potato in restoring the normal liver, kidney and heart weights of negative control rats. The non-significant $(P>0.05)$ differences in organ weights were observed between reduced fat cupcake diets at $2.5 \%$ and $5 \%$ replacement level.

\section{Effect of baked sweet potato cupcake on lipids profile}

Positive control rats and rats fed control cupcake diet had higher $(P \leq 0.05)$ triglyceride (TG), total cholesterol (TC), and low-density lipoprotein (LDL) values than negative control rats and obese rats fed reduced fat cupcake diets Table (3). However, high-density lipoprotein (HDL) had an opposite trend. The high lipid levels in plasma may be due to increased uptake of exogenous lipid and decreased lipid catabolism. The similar results were reported by Walatara et al. (2014) who found that obese male and female rats had higher TC and LDL as well as lower HDL values than non-obese males and females. Sunarti, et al., (2016) showed that the administration of a high-fat diet for 25 days increases cholesterol and reduces $\mathrm{HDL}$.

The non-significant $(P>0.05)$ differences in TG, TC, LDL and HDL values were observed between positive control rats and rats fed control cupcake diet. However, TG, TC, and LDL values were significantly $(\mathrm{P} \leq 0.05)$ decreased by increasing the replacement level of baked sweet potato in reduced fat cupcake diets as compared with positive control rats and obese rats fed control cupcake diet. However, HDL values had an opposite trend. The reduction in triglycerides and lipoproteins may be due to the high content of bioactive compounds in sweet potatoes such as carotenoids, anthocyanin, phenolic acids, and flavonoids. These findings are in accordance with those reported by Shin et al., (2013) who reported that feeding obese mice with sweet potato enhanced the decreases of serum triglyceride, total cholesterol, and LDL cholesterol. Kan et al., (2014) found that sweet potato reduced serum triglyceride, total cholesterol, and LDL concentration and increased serum HDL concentration in treated rats.

Reduced fat cupcake diets at $\mathbf{5 \%}$ replacement level were more effective $(P \leq 0.05)$ in reducing TG, TC and LDL values than reduced fat cupcake diets at 2.5\% replacement level. However, a nonsignificant $(P>0.05)$ difference in HDL values was observed between reduced fat cupcake diets at $2.5 \%$ and $5 \%$ replacement level. Reduced fat cupcake at $80 \%$ replacement level of baked sweet potato was more effective $(P \leq 0.05)$ in reducing TG, TC, and LDL values and increasing HDL values than other replacement levels of baked sweet potato. The reduction in TG, TC and LDL values and increase in HDL values of the rats fed reduced fat cupcake at $80 \%$ replacement level of baked sweet potato diets was $25.80,37.08$, and $51.91 \%$ and 


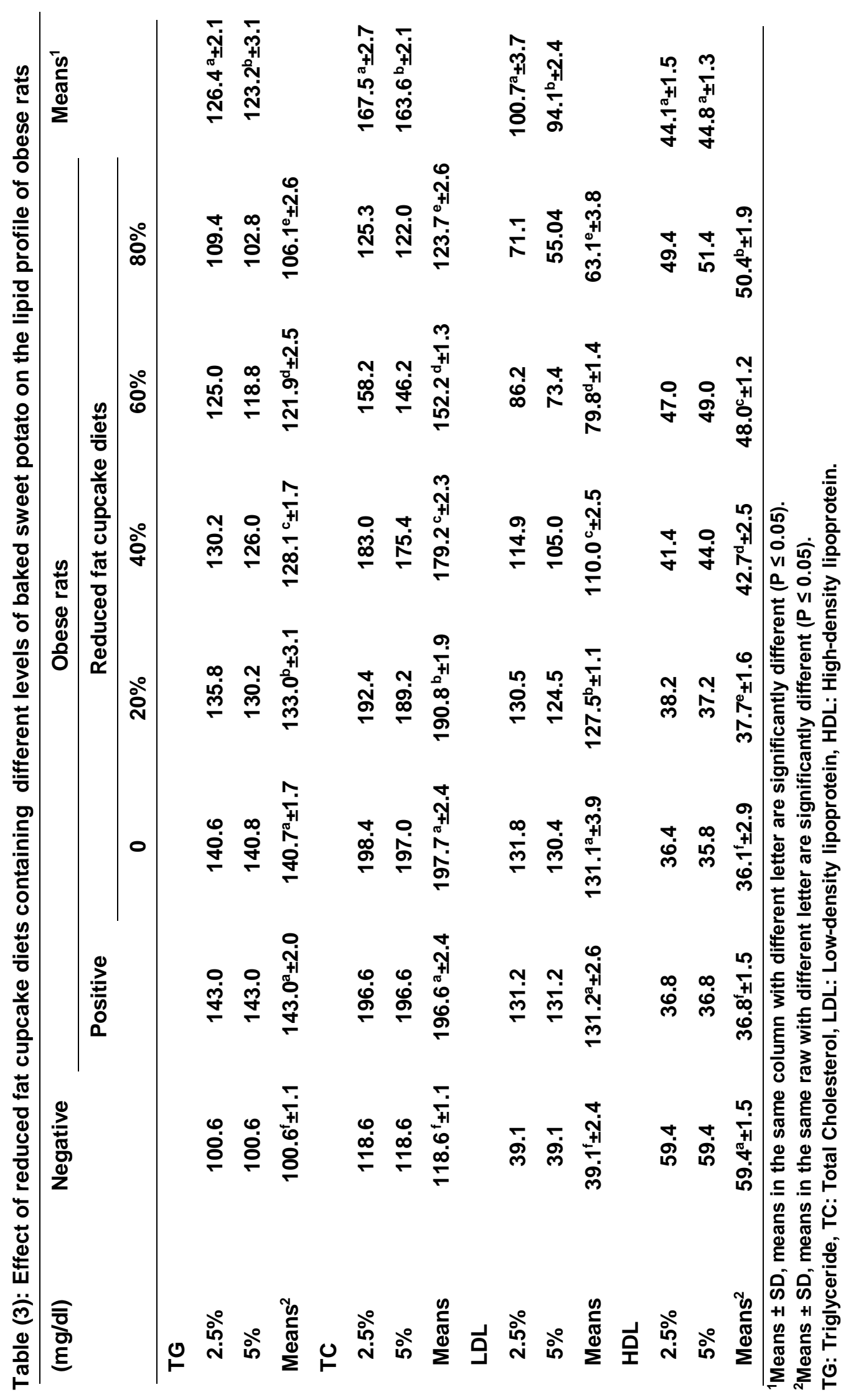


$36.96 . \%$, respectively as compared with positive control rats. Srijita, (2015) showed that consumption 4 grams daily of sweet potato extract for three months resulted in reducing the levels of TC and LDL by 30 and $13 \%$, respectively. Although reduced fat cupcake at different replacement levels of sweet potato decreased TG, TC and LDL and increased HDL values in the obese rats, their values were still higher and lower, respectively than negative control rats. This may be due to the short trial period.

\section{Effect of baked sweet potato} cupcake on blood glucose

Positive control rats and rats fed control cupcake diet had higher ( $P \leq 0.05)$ blood glucose levels than negative control rats and obese rats fed reduced fat cupcake diets Table (4). Obesity adds pressure on rat body ability to use insulin to properly control blood sugar levels. A non-significant $(P>0.05)$ difference in blood glucose level was observed between positive control rats and rats fed control cupcake diet. However, blood glucose level was significantly $(P \leq 0.05)$ decreased by increasing the replacement level of baked sweet potato in reduced fat cupcake diets as compared with positive control rats and obese rats fed control cupcake diet. Sweet potato may be beneficial for diabetes because it helps in stabilizing blood sugar levels and lower insulin resistance (Milind and Monika, 2015). Srijita, (2015) found that sweet potato is high in fiber and have a low glycemic index which can help diabetics control their blood sugar. Moch et al., (2010) showed that administration of an extract of sweet potato at a dose of 200 $\mathrm{mg} / \mathrm{kg}$ for two weeks caused a significant reduction in blood glucose.

A non-significant $(P>0.05)$ difference in blood glucose level was observed between reduced fat cupcake diets at $2.5 \%$ and $5 \%$ replacement level. Reduced fat cupcake at $80 \%$ replacement level of baked sweet potato was more effective $(P \leq 0.05)$ in reducing blood glucose levels than other replacement levels of baked sweet potato. The reduction in blood glucose level of the rats fed reduced fat cupcake at $80 \%$ replacement level of baked sweet potato diets was $15.98 \%$ as compared with positive control rats. Although reduced fat cupcake at different replacement levels decreased blood glucose levels in the obese rats, their values were still higher than negative control rats. This may be due to the short of the trial period.

Table (4): Effect of reduced fat cupcake diets containing different levels of baked sweet potato on blood glucose of obese rats

\begin{tabular}{|c|c|c|c|c|c|c|c|c|}
\hline \multirow[t]{3}{*}{ (mg/dl) } & \multirow[t]{3}{*}{ Negative } & \multicolumn{6}{|c|}{ Obese rats } & \multirow[t]{3}{*}{ Means $^{1}$} \\
\hline & & \multirow[t]{2}{*}{ Positive } & \multicolumn{5}{|c|}{ Reduced fat cupcake diets } & \\
\hline & & & $0 \%$ & $20 \%$ & $40 \%$ & $60 \%$ & $80 \%$ & \\
\hline $2.5 \%$ & 83.0 & 102.6 & 102.4 & 97.6 & 94.0 & 90.2 & 86.8 & $\begin{array}{r}93.8 \\
a_{ \pm}+2.9\end{array}$ \\
\hline $5 \%$ & 83.0 & 102.6 & 102.2 & 96.6 & 92.8 & 89.4 & 85.6 & $\begin{array}{r}93.2 \\
a_{ \pm} 2.6\end{array}$ \\
\hline
\end{tabular}

Means $^{2} \quad 83.0^{\mathrm{f}} \pm 1.5 \quad 102.6^{\mathrm{a}} \pm 3.9102 .3^{\mathrm{a}} \pm 1.6 \quad 97 . .^{\mathrm{b}} \pm 2.3 \quad 93.4^{\mathrm{c}} \pm 1.6 \quad 89.8^{\mathrm{d}} \pm 1.3 \quad 86.2^{\mathrm{e}} \pm 1.7$

\footnotetext{
${ }^{1}$ Means \pm SD, means in the same column with different letter are significantly different $(P \leq 0.05)$.

${ }^{2}$ Means \pm SD, means in the same raw with different letter are significantly different $(P \leq 0.05)$.
} 
Effect of baked sweet potato cupcake on kidney functions

Kidney removes metabolic wastes such as urea, uric acid, and creatinine. The concentrations of the metabolites increase in blood during renal diseases or renal damage may due to high activities of xanthine oxidase, lipid peroxidation, and increased triacylglycerol and cholesterol levels (Anwar and Meki, 2003). Positive control rats and rats fed control cupcake diet had higher $(P \leq 0.05)$ blood urea, serum uric acid, and serum creatinine values than the negative control (Table 5). Obesity causes increased blood pressure which produces unfavorable effects and such a change in kidney resulting in increased tubular secretions leading to increased blood urea and creatinine and uric acid level (Kovesdy et al., 2017). Blood urea and serum uric acid were not affected $(P>0.05)$ by baked sweet potato at any replacement level. However, serum creatinine was significantly $(P \leq 0.05)$ decreased by increasing the replacement level of baked sweet potato in reduced fat cupcake diets as compared with positive control rats and obese rats fed control cupcake diet. Salmean et al. (2013) conclude that increasing fiber intake in chronic kidney disease patients may reduce serum creatinine level.

A non-significant $(P>0.05)$ difference in serum creatinine was observed between reduced fat cupcake diets at $2.5 \%$ and $5 \%$ replacement level. Reduced fat cupcake at $80 \%$ replacement level of baked sweet potato was more effective $(P \leq 0.05)$ in reducing serum creatinine than other replacement levels of baked sweet potato. The reduction in serum creatinine of the rats fed reduced fat cupcake at $80 \%$ replacement level of baked sweet potato diets was $14.04 \%$ as compared with positive control rats. A non-significant $(P>0.05)$ difference in serum creatinine was observed between negative control rats and rats fed reduced fat cupcake at $80 \%$ replacement level of baked sweet potato. Data indicate that feeding obese rats with a reduced fat cupcake at $80 \%$ replacement level of baked sweet potato for 30 days led to restore the normal serum creatinine of negative control rats.

\section{Effect of baked sweet potato cupcake on liver functions}

Several hepatic enzymes in serum were used for the biochemical markers to understand the early hepatic injury, such as alkaline phosphatase (ALP), alanine aminotransferase (ALT), and aspartate aminotransferase (AST) (Giannini et al., 2005). Positive control rats and rats fed control cupcake diet had higher ( $P \leq 0.05)$ ALP, ALT and AST enzymes than the negative control rats (Table 6). Marchesini et al. (2008) reported that the presence of obesity increases the risk of elevated liver enzymes. The ALP, ALT, and AST enzymes were significantly $(P \leq 0.05)$ decreased by the replacement levels of baked sweet potato in reduced fat cupcake diets as compared with positive control rats and obese rats fed control cupcake diet. A non-significant $(P>0.05)$ difference in ALP enzyme was observed among the replacement levels of baked sweet potato in reduced fat cupcake diets.

Rats fed $\mathbf{4 0}$ to $\mathbf{8 0 \%}$ replacement levels of baked sweet potato in reduced fat cupcake diets had lower ( $P \leq 0.05)$ ALT enzyme than those fed $20 \%$ replacement level of baked sweet potato in reduced fat cupcake diet. However, non-significant $(P>0.05)$ difference in ALT enzyme was observed among 40, 60 and $80 \%$ replacement levels of baked sweet potato in reduced fat cupcake diets. Jung et al., (2015) showed that pretreatment with extract of sweet potato decreased ALT and AST serum levels in hepatic rats. 


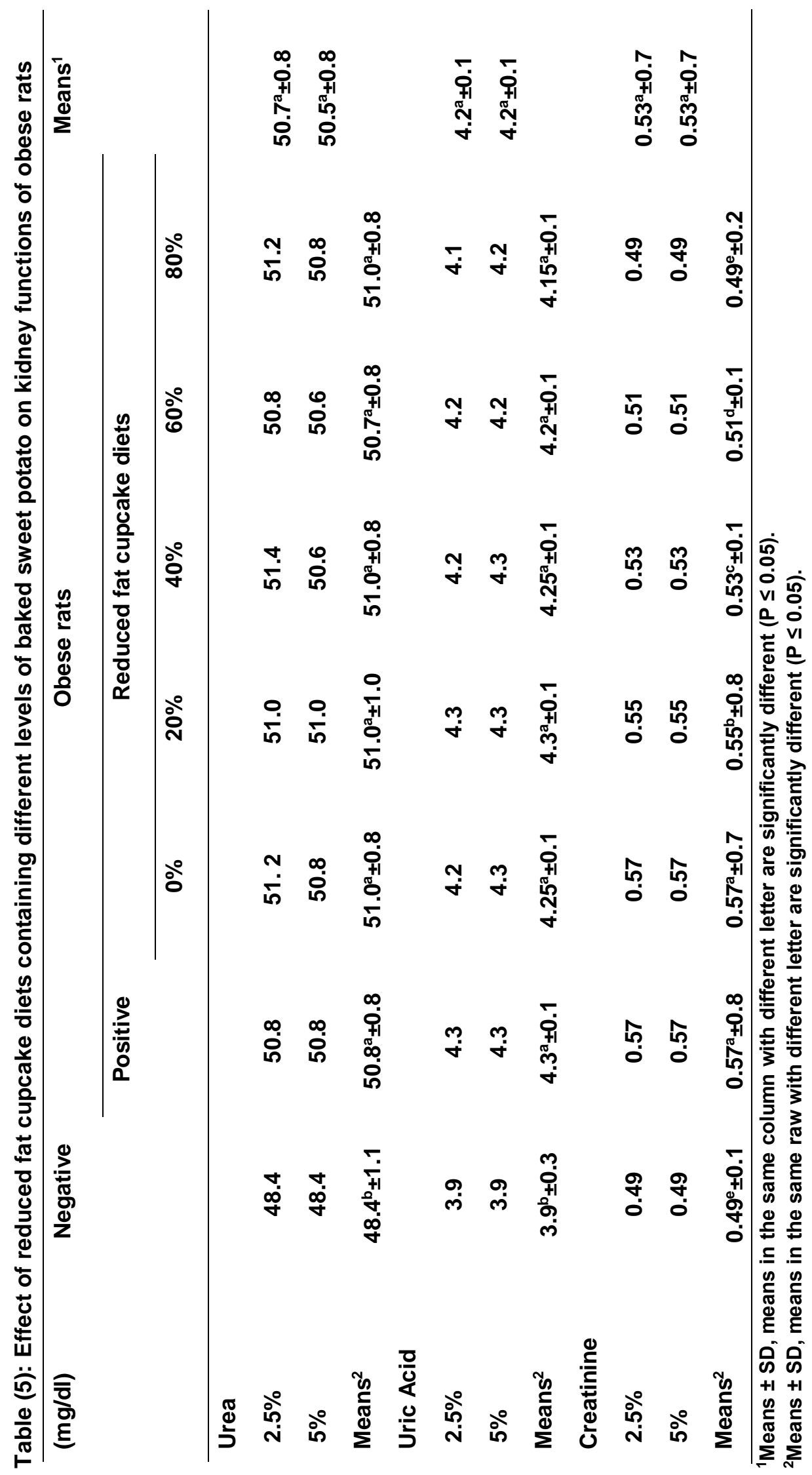


A. A. Hafez, et al.,

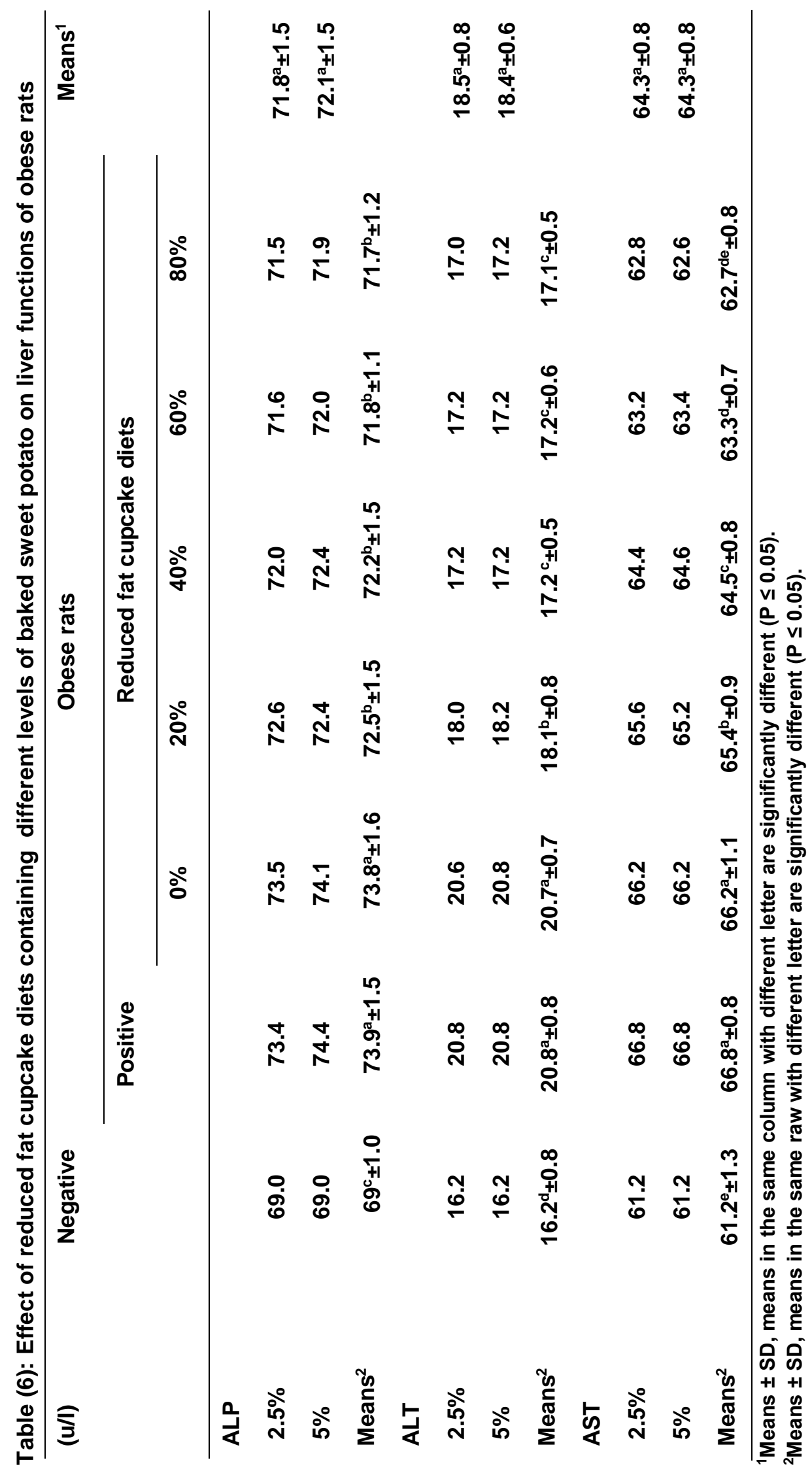


Shin et al., (2013) showed that sweet potato extract lowered ALT and AST enzymes and decreases hepatic injury.

The non-significant $(P>0.05)$ differences in ALP, ALT and AST enzymes were observed between reduced fat cupcake diets at $2.5 \%$ and $5 \%$ replacement level. Reduced fat cupcake at $80 \%$ replacement level of baked sweet potato was more effective (PS0.05) in reducing AST enzyme than other replacement levels of baked sweet potato. The reduction in the AST enzyme of the rats fed reduced fat cupcake at $80 \%$ replacement level of baked sweet potato diets was $6.14 \%$ as compared with positive control rats. A non-significant $(P>0.05)$ difference in AST enzyme was observed between negative control rats and rats fed reduced fat cupcake at $80 \%$ replacement level of baked sweet potato. Data indicate that feeding obese rats with a reduced fat cupcake at $80 \%$ replacement level of baked sweet potato for $\mathbf{3 0}$ days led to restoring the normal AST enzyme level of negative control rats. The reduction in ALP and ALT enzymes of the rats fed reduced fat cupcake at different replacement levels of baked sweet potato diets were ranged from 1.89 to $2.98 \%$ and 12.98 to $17.79 \%$, respectively as compared with positive control rats. Although reduced fat cupcake at different replacement levels decreased ALP and ALT enzymes in the obese rats, their values still higher than negative control rats. This may be due to the short of the trial period.

\section{CONCLUSION}

From the above results, it could be concluded that feeding obese rats with reduced fat cupcake prepared with baked sweet potato proved to be effective in improving the body weight gain, organ weight, TG, TC, LDL, blood glucose level, liver function, and serum creatinine.

\section{REFFRENCES}

Allian, C.C. (1974). Enzymatic determination of total serum cholesterol. Clin Chem., 20: 470-475.

Alloush, S. A. (2015). Chemical, physical and sensory properties of sweet potato cake Egypt. J. Agric. Res., 93 : 101-115

Anwar, M.M. and A.R. Meki (2003). Oxidative stress in streptozotocin induced diabetic rats : effects of garlic oil and melatonin. Comp Biochem Physiol A mol Integr Physiol : 135:53947

Assmann, G.(1979). HDL cholesterol precipitant. Randox Labs. Ltd. Curmlin Co.Antrim. N.Irland. Internist. 20: 559567

Barham, D. and P. Trinder (1972). Quantitative enzymatic colorimetric determination of uric acid in serum, plasma or urine. Analyst, 97: 142-145.

Burri, B.J. (2011). Evaluating sweet potato as an intervention food to prevent vitamin A deficiency. Compr. Rev. Food Sci. Food Safety. 10: 118130.

Campbell, J. A. (1961). Methodology of Protein Evaluation RAG Nutr., Document R. 10 Led., 37. WHO; June Meeting New York.

Chapman, D.G., R. Castilla and J.A. Campbell (1959). Evaluation of protein in foods: 1. A method for the determination of protein efficiency ratios.Canadian J. of Biochemistry and Physiology, 37: 679-686

Drury, R.A. and E.A. Wallington (1980). Carton's Histological Technique, 5th Ed., Oxford Univ.London, U.K

Fossati, P. and L. Prencipe (1982). Serum triglycerides determined colorimetrically with an enzyme that produces hydrogen peroxide. Clin Chem., 28:2077-80. 
Giannini, E. G, R. Testa and V. Savarino (2005). Liver enzyme alteration: a guide for clinicians 1;172(3): 367-79 .

Gutmann, I. and H.U. Bergmeyer (1974). Determination of Urea with Glutamate Dehydrogenase as Indicator Enzyme. 2nd Edn., Academic Press, New York, pp: 1794-1798.

Hagenimana, V., E.E. Carey, S.T. Gichuki, M.A. Oyunga and J.K. Imungi (1998). Carotenoid content after drying and processing sweetpotato products. Ecol Food Nutr 37: 450-473.

Hayssement, T. U. (1977). Determination of alkaline phosphatase. Clinica Chimica Acta, 35: 271-273.

Hegested, A. (1941). Salt Mixture. J. Bio. Chem., 138:459.222.

Houot, O. (1985). Kinetic determination of Creatinine. In: Interpretation of Clinical Laboratory Tests, Henny, J., G. Siest, F. Schiele and D.S. Young (Eds.). Biomedical Publications, California, USA., pp: 220-234.

Ji, H., H. X. Zhang, H. T. Li and Y. C. Li (2015). Analysis on the Nutrition Composition and Antioxidant Activity of Different Types of Sweet Potato Cultivars. Food and Nutrition Sciences, 6: 161-167.

Jung, S. B., J. H. Shin, J. Y. Kim and 0. Kwon (2015). Shinzami Korean purple fleshed sweet potato extract prevents ischaemia-reperfusion-induced liver damage in rats. Journal of the Science of Food and Agriculture, 95: 28182823.

Kan, J., H. Shi, X. Liu and Z. Chen (2014). Hypolipidemic effect of proteoglycans isolated from sweet potato (Ipomoea batatas LAM) in hyperlipidemia rats. Food Science and Biotechnology, 23: 2021-2028

Kang, S. A., K. H. Jang, K. Hong, S. Kim, M. K. Kim, I. Y. Lee and Y. H. Lim (2005). Effect of yeast beta-glucan on serum lipids and leptin levels in the diet-induced obese rats. Asiapac. J. Clin. Nutr., 14: SII4.

Kovesdy, C. P., S. L. Furth and C. Zoccali (2017). Obesity and kidney disease hidden consequences of the epidemic. National Institute of Health Feb;30:110. doi: 10.1177/2054358117698669

Kumar, V., U. Bhandari, C. Tripathi and G. Khanna (2012). Evaluation of antiobesity and cardioprotective effect of Gymnema . sylvestre extract in murine model. Indian J Pharmacol., 44: 607-613.

Lee, R.D. and D.C. Nieman (1996). In Nutrition assessment. 2nd ed. MosbyYear Book, St Louis, Mo: 195-197.

Marchesini, G., S. Moscatiello, S. Di Domizio and G. Forlani (2008). Obesity-associated liver disease.The Journal of Clinical Endocrinology \& Metabolism, 93: 74-80.

Milind, P. and Monika (2015). Sweet potato as supper-food. Res. Ayurveda Pharma., 6: 557-562

Moch, S. B., W. J. Hye, C. Jongwon and P. Jong-Ok (2010). Protective Effect of White-Skinned Sweet Potato (Ipomoea batatas L.) from Indonesia on Streptozotocin-Induced Oxidative Stress in Rats Journal of Life Science Vol. 20: 1569-1576.

Mohanraj, R. and S. Sivasankar (2014). Sweet potato (Ipomoea batatas [L. ] Lam)- -a valuable medicinal food: a review. J, Med, Food. 17: 733-741.

Reeves, P.G., F.H. Nielsen and GC. Jr. Fahey (1993). AIN-93 purified diets for laboratory rodents: final report of the American Institute of Nutrition Ad Hoc Writing Committee on the Reformulation of the AIN-76A Rodent Diet. J Nutr 123: 1939-1951

Reitman, S. and S. Frankel (1957). Determination, of alanine aminotranspherase and aspartate aminotranspherase. Amer. J. of Clin. Path., 28: 57-63. 
Rodriguez-Amaya, DB, MR Nutti and V. Carvalho (2011). Carotenoids of sweet potato, cassava, and maize and their use in bread and flour fortification. In: Preedy VR, Watson RR and Patel VB (Eds), Flour and breads and their fortification in health and disease prevention. London: Academic Press, p. 301-311.

Salmean, Y. A., M. S. Segal, B. angkampHenken, T. Canales, D. A. Zello and W. J. Dahl (2013). Foods with added fiber lower serum creatinine levels in patients with chronic kidney disease. Journal of Renal Nutrition, 23: 29-32.

Schermer, S. (1967). The Blood Morphology of Laboratory Animals. Green and Co., Ltd., Longmans, pp: 350-355.

Shin, S. J., U.J. Bae, M. Ahn, S.O. Ka, S.J. Woo, S.O. Noh and B.H. Park (2013). Aqueous extracts of purple sweet potato attenuate weight gain in high fat fed mice. International journal of pharmacology, 9: 42-49.

Srijita, D. (2015). Sweet Potatoes For Diabetes Mellitus A Systematic Review. Pharmacophore An International Research Journal 6 (1): 60-72

Srivastava, S., T. R. Genitha and V. Yadav (2012). Preparation and Quality Evaluation of Flour and Biscuit from Sweet Potato. J Food Process Technol. 3: 192.

Sudha, M. L., V. Baskaran and K. Leelavathi (2007). Apple pomace as a source of dietary fiber and polyphenols and its effect on the rheological characteristics and cake making. Food Chemistry, 104: 686692.

Sunarti, S., S. R. Dianandha and H. S. Ahmad (2016). The effect of pumpkin on Glp-1 and Homa-B Hypercholesterolemic rats.rom $j$ diabetes nutr metab dis. (23) 1: 019025.

Trinder, P. (1969). Determination of glucose in blood using glucose oxidase with an alternative oxygen acceptor. Ann Clin Biochem; 6: 24-25.

Trinidad, P. T., S. S. Rosario, C. M. Aida, S. B. Melissa, P. D. Marco and F. A. Theressa (2013). Sweet Potato and Cassava Can modify cholesterol profile in humans with moderately raised serum Cholesterol levels. Food and Nutrition Sciences, 4: 491-495.

Tsuda, T., F. Horio and T. Osawa (1998). Dietary cyanidin 3-0-Beta-dglucoside increases ex vivo oxidation resistance of serum in rats. Lipids, 33: 583-588.

Van jaarsveld, P.J., M. Faber, SA Tanumihardjo, P. Nestel, CJ Lombard and AJ. Benadé (2015). Beta-carotenerich orange-fleshed sweet potato improves the vitamin $A$ status of primary school children assessed with the modified-relative-dose-response test. Am J Clin Nutr. 81: 1080-7.

Walatara, K., F. Nusha, A. Kaneshapillai, L. Athiththan, R. Perera and U. Hettiaratchi (2014). Effect of central obesity on serum lipid profile in nondiabetic, non-hypertensive subjects- A preliminary study International Journal of Multidisciplinary Studies, 1: 123-129. 
التأثير الوقائي للكيك المصنع باستبدال الدهن بمستويات مختلفه من البطاطا الحلوة

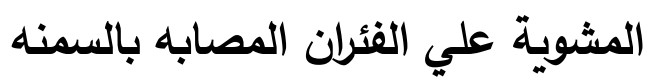

أسماء علي حافظ(')، هبه عز الدين يوسف(ץ)، عصام الدين حافظ منصور (1)،

علي حسن خليل(1)

(1) قسم علوم وتكنولوجيا الأغذية ، كلية الزراعة، جامعه المنوفيه

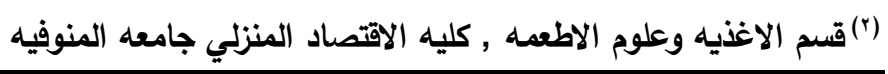

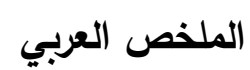

إزداد الإهتمام فى الآونة الأخيرة لإكتثاف منتجات طبيعية كبديل للدهون فى المنتجات الغذائية لإنتاج أغذية صحية

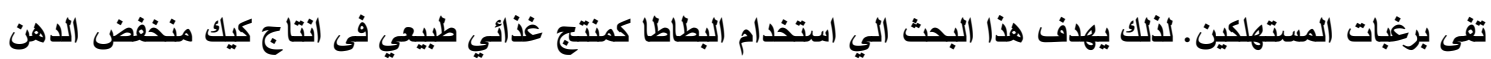

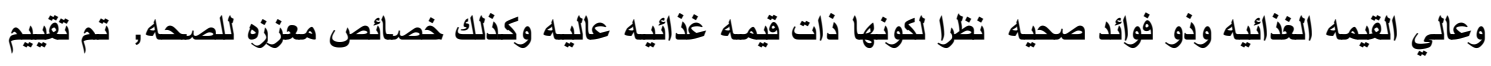

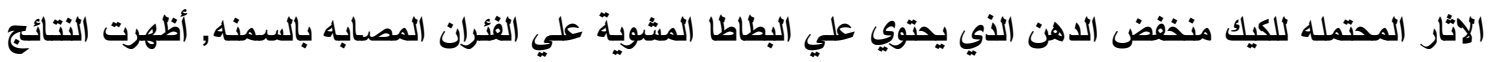

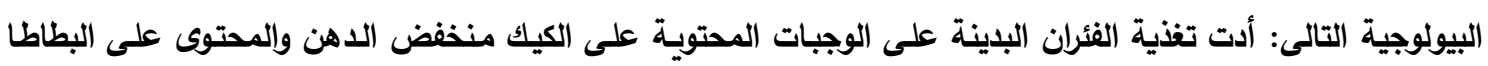

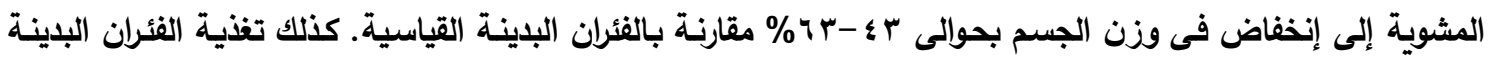

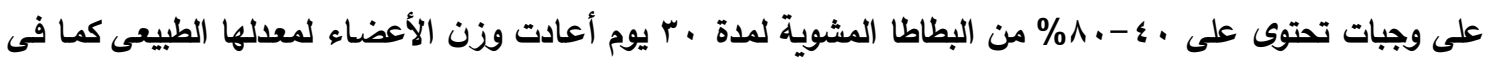

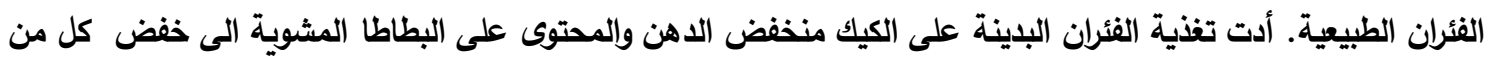

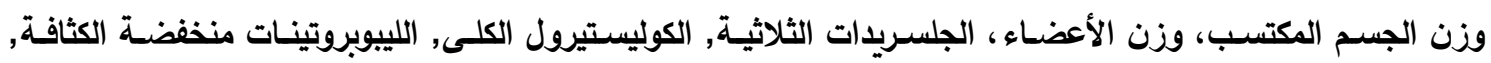

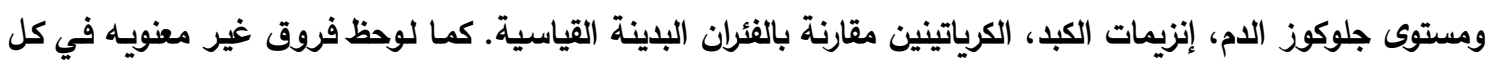

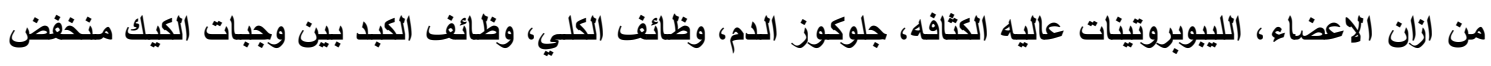

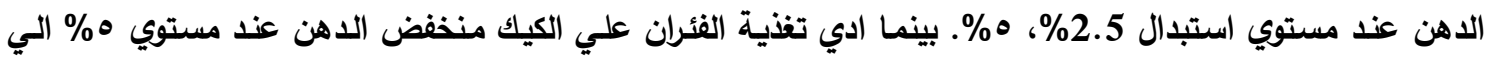

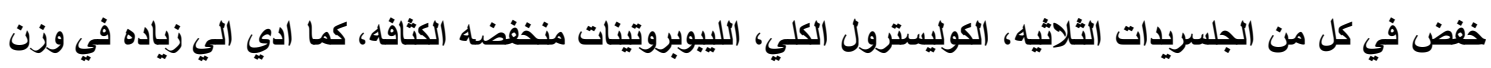

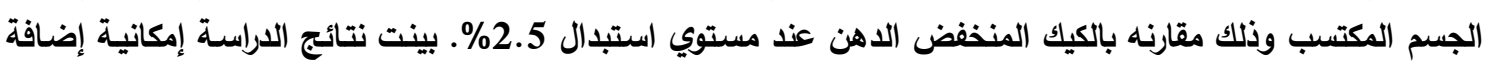
البطاطا المشوية كمنتج طبيعى الى صناعة الكيك للحصول على منتج صحى عالى القيمة الغذائية وكذلك تحسين السمنه.

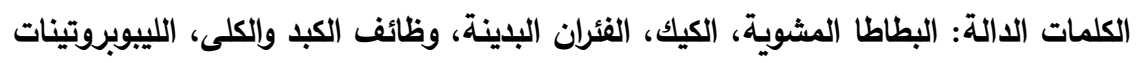

أسماء السادة المحمين

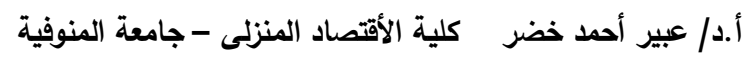

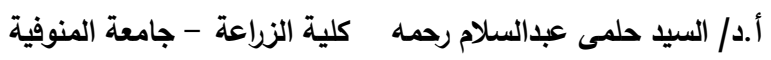

